\title{
POLUBOWNE ROZSTRZYGANIE SPORÓW ADMINISTRACYJNYCH WEDŁUG PRZEPISÓW KOŚCIOŁA ŁACIŃSKIEGO
}

Treść: Uwagi wstępne. - 1. Posoborowa reforma sprawiedliwości administracyjnej w Kościele. - 2. Przedmiot polubownych środków odwoławczych. - 3. Prośba do autora aktu o odwołanie go lub poprawienie. - 3.1. Rys historyczny. - 3.2. Prośba do autora aktu w aktualnych przepisach kodeksowych. - 3.3. Skutki wniesienia prośby o odwołanie aktu administracyjnego. - 4. Zwrócenie się obu stron do mediatorów. - 5 . Odwołanie się do urzędu lub komisji pojednawczej. - Uwagi końcowe.

\section{Uwagi wstępne}

Ochrona praw osób fizycznych i prawnych należy do zasadniczych funkcji władzy i systemu prawnego każdego organizmu społecznego. Nowe spojrzenie na Kościół, szczególnie po Soborze Watykańskim II, zachęciło do postulowania daleko idącej ochrony praw podmiotowych w Kościele. Podczas pierwszego zgromadzenia ogólnego Synodu Biskupów w roku 1967 zostały zatwierdzone Zasady, według których miała się dokonać reforma Kodeksu Prawa Kanonicznego. Po dość pozytywnej ocenie sądownictwa kościelnego, znalazły miejsce również ostre stwierdzenia dotyczące możliwości obrony praw wiernych wobec organów kościelnej władzy wykonawczej. W numerze siódmym wspomnianych Zasad odnotowano poważne braki w tym względzie. Wielu kanonistów już dużo wcześniej postulowało tego typu niedomagania systemu sprawiedliwości administracyjnej w Kościele.

Istnienie konfliktów na łonie Kościoła jest nieuniknione, bowiem jest on złożony z niedoskonałych ludzi. Spory mogą występować tak pomiędzy równymi jak i pomiędzy władzą i poddanymi z motywu aktu 
rządzenia ${ }^{1}$. Jednak wciąż istnieje obowiązek unikania ducha kłótni czy sporu (Tyt 3, 1-2; 1 Tm 3, 3; 2 Tm 2, 23-24), który winien być zastąpiony przez ducha łagodności (1 Kor 13, 4-7), by ,zachowując sprawiedliwość, na ile to możliwe, wykluczyć spory w Ludzie Bożym i jak najszybciej pokojowo je rozwiązywać" (can. 1446 §1)2. Można więc postawić tezę, że ewangeliczny nakaz zapobiegania sporom poprzez szukanie dróg pojednania ${ }^{3}$, znajduje odzwierciedlenie w kanonicznym zaleceniu unikania konfliktów bądź dążenia do ich rozstrzygnięcia w drodze ugody czy sądu polubownego ${ }^{4}$.

\section{Posoborowa reforma sprawiedliwości administracyjnej w Kościele}

Sekcja pierwsza piątej części Księgi siódmej Procesy aktualnie obowiązującego Kodeksu z 1983 r., zatytułowana Rekursy przeciw dekretom administracyjnym, zawiera zasadniczo nowe normy w stosunku do Kodeksu z 1917 r. W starym prawie odwołanie się mogło mieć miejsce jedynie od dekretów ordynariuszy za pomocą rekursu hierarchicznego do kongregacji Kurii Rzymskiej (kan. 1601). W okresie posoborowym, szczególnie w okresie prac nad przygotowaniem nowego Kodeksu Prawa Kanonicznego, system ów został skrytykowany ze względu na brak odpowiedniej ochrony praw wiernych i niewystarczający obiektywizm decyzji rozstrzygających spór administracyjny. Papież Paweł VI przeprowadzając reformę Kurii Rzymskiej mocą konstytucji Regimini Ecclesiae Universae (15.08.1967), przywrócił sądową kontrolę nad działalnością administracji kościelnej (art. 106), zniesioną przez Piusa X w 1908 r. (Konst. Ap. Sapienti Consilio).

Nowością w stosunku do KPK z 1917 r. jest ustanowienie przez nowy Kodeks środków odwoławczych, które zmierzają do zapobieżenia po-

${ }^{1}$ E. LabandeIra, Trattato di diritto amministrativo canonico, Milano 1994, s. 455.

2 J. Miras, J. Canosa, E. Baura, Compendio di diritto amministrativo canonico, Roma 2007, s. 330.

${ }^{3}$ Mt 5, 9; 18, 15-16; Mk 9,49. Por. J. Krukowski, Prawo administracyjne w Kościele, Warszawa 2011, s. 512.

4 P. Majer (red.), Kodeks Prawa Kanonicznego. Komentarz, ed. polska, Kraków 2011, s. 1301. 
wstaniu sporu administracyjnego. Tego rodzaju środki zostały wysunięte przez Papieską Komisję do Spraw Reformy KPK, która zgłosiła nowy model systemu sprawiedliwości administracyjnej w schemacie De procedura administrativa $a^{5}$, który w 1972 r. został rozesłany konferencjom biskupów i dykasteriom Kurii Rzymskiej do zaopiniowania. Projekt został zaaprobowany przez biskupów w nadesłanych przez nich uwagach. W schemacie tym zostały zaproponowane dwa rodzaje środków prawnych przeciwko wadliwym aktom administracyjnym. Na pierwszym miejscu zostały wymienione środki, które mają na celu zapobiec powstaniu sporu administracyjnego. Temu miała służyć prośba do autora aktu administracyjnego o ponowne rozpatrzenie sprawy i ewentualne odwołanie lub poprawienie dekretu oraz zwrócenie się obu stron zainteresowanych, tzn. jednostki administrowanej, będącej adresatem aktu, i organu kościelnej władzy administracyjnej, będącego autorem tego aktu, do sądu polubownego lub komisji pojednawczej (kan. 1733-1734). W wypadku gdyby zastosowanie powyższych środków nie przyczyniło się do pogodzenia stron, jednostka administrowana mogła zwrócić się do organów władzy kościelnej o rozpatrzenie i rozstrzygnięcie sporu przez wniesienie środków odwoławczych w ścisłym tego słowa znaczeniu, a mianowicie rekursu hierarchicznego z jakiegokolwiek słusznego motywu (kan. 1735-1739) oraz rekursu do trybunału administracyjnego z motywu nielegalności aktu administracyjnego lub z motywu naprawienia szkody wynikłej z nielegalnego aktu (kan. 1445 §2) ${ }^{6}$.

Zgodność stanowisk Papieskiej Komisji do Spraw Reformy KPK i konsultowanych konferencji biskupów i dykasterii Kurii Rzymskiej, co do możliwości zastosowania środków polubownych przed ewentualnym sporem administracyjnym, była motywowana tym, że tego rodzaju środki o charakterze raczej pastoralnym aniżeli ściśle prawnym bardziej odpowiadają duchowi Kościoła, kierującego się miłością bra-

5 Pierwsza wersja schematu procedury administracyjnej była przedstawiona w 1970 r.; por. Communicationes 2(1979) s. 191-194; 4(1972), s. 36-38. Druga wersja - w 1972 r.; Schema canonum de procedura administrativa, Typis Polyglottis Vaticanis 1972.

${ }^{6}$ G. Erlebach, A. Dzięga, J. Krukowski (red.), R. Sztychmiler, Komentarz do Kodeksu Prawa Kanonicznego, t. 5, Księga VII. Procesy, Poznań 2007, s. 421. 
terską w stosunkach nie tylko między poszczególnymi wiernymi, ale również między wiernymi a przełożonymi ${ }^{7}$.

Wprowadzając środki pojednawcze do Kodeksu Prawa Kanonicznego z 1983 r. prawodawca sięgnął zarówno do tradycji kanonistycznej ${ }^{8}$, jak również do współczesnych form rozwiązywania konfliktów między jednostką i władzą w niektórych regionach, a zwłaszcza w krajach pozostających w kręgu kultury anglosaskiej. Środki mające za cel bezpośredni niedopuszczenie do powstania sporu administracyjnego w sensie formalnym (kan. 1733-1734), których zastosowanie jest nakazane bądź zalecane przez prawodawcę, są następujące: prośba do autora dekretu o odwołanie go lub poprawienie, zwrócenie się obu stron do mediatorów, skierowanie sprawy do rozpatrzenia przez urząd lub komisję ustanowioną przez konferencję biskupów lub poszczególnego biskupa ${ }^{9}$.

\section{Przedmiot polubownych środków odwoławczych}

Mówiąc o środkach pojednawczych, stosowanych wobec wadliwych aktów administracyjnych, należy sprecyzować, jakich aktów dotyczyć będą wspomniane środki. Prawodawca określa zakres przedmiotowy tychże aktów w kan. 1732, wskazując, iż są to wszystkie akty administracyjne poszczególne, zwłaszcza zaś dekrety i nakazy konkretne, czyli takie oświadczenia woli podmiotów kościelnej władzy administracyjnej, które rodzą określone skutki prawne dla osób hierarchicznie podlegających tymże podmiotom, wydane w zakresie zewnętrznym pozasądowym. Aktami niezaskarżalnymi natomiast są: dekrety ogólne organów władzy ustawodawczej lub wykonawczej; akty

7 Por. J. Krukowski, Prawo administracyjne w Kościele, s. 511; M. Lefebvre, De nonnullis technicis animadversionibus episcoporum in schema „De procedura administrativa”, Ephemerides Iuris Canonici 29(1973), s. 198; P. CIPROTTI, Relatio de animadversionibus quae factae sunt ad schema canonum ,De procedura administrativa" ab Episcopalibus Conferentiis et a Sanctae Sedes Dicasteriis, Communicationes 5(1973), s. 239.

${ }^{8}$ G. Erlebach, A. Dzięga, J. Krukowski (red.), R. Sztychmiler, Komentarz do Kodeksu Prawa Kanonicznego, t. 5, s. 421.

9 J. KruKowsKi, Administracja w Kościele, Lublin 1985, s. 204-205. 
administracyjne konkretne wydane przez podmioty władzy sądowniczej na etapie rozpoznawania sprawy; akty administracyjne konkretne wydane w zakresie wewnętrznym tak sakramentalnym jak i pozasakramentalnym przez Penitencjarię Apostolską; akty administracyjne wydane przez Biskupa Rzymu mocąjego władzy prymacjalnej oraz przez Sobór Powszechny. Można natomiast zaskarżyć akty administracyjne konkretne wydane przez dykasterie Kurii Rzymskiej, pełniące funkcje administracyjne, chyba że uzyskały one aprobatę Biskupa Rzymu, wydaną w formie specyficznej (por. kan. 1405 §2). Nie można także zaskarżyć aktów administracyjnych konkretnych mających charakter jedynie przygotowawczy, których autorem jest kolegialny organ konsultacyjny, wyrażający radę bądź opinię odnośnie do legalności lub poprawności merytorycznej danego aktu administracyjnego, przed wydaniem definitywnego aktu konkretnego przez organ kościelnej władzy wykonawczej. Akty te bowiem, same z siebie nie rodzą skutków prawnych. W przypadku zaś pominięcia wymaganej przez prawo opinii bądź zgody kolegialnego organu konsultacyjnego, jeżeli z aktu takiego wynikła szkoda, można zastosować przeciwko niemu środek odwoławczy ${ }^{10}$.

\section{Prośba do autora dekretu o odwołanie go lub poprawienie}

Ten najprostszy sposób zapobieżenia powstaniu sporu praktykowany był w Kościele od początków jego istnienia. Do przełożonego, którego nakaz spowodował jakąś szkodę bądź nakładał nadmierny ciężar, wnoszono suplikację (supplicatio) nazywaną później rekursem łaski (recursus gratiae). Celem prośby do autora krzywdzącego aktu administracyjnego była chęć uchylenia się od obowiązku przestrzegania go w życiu. Znane były także inne tego typu środki zaradcze jak oppositio, remonstratio, beneficium novae audientiae, aperitio oris. Wzmianki o tymże środku odwoławczym znajdują się już w Dekrecie Gracjana oraz w prawie dekretałów. W późniejszym czasie nie budził on większego zainteresowania ani w praktyce, ani w nauce prawa, pojawia-

${ }^{10}$ G. Erlebach, A. Dzięga, J. Krukowski (red.), R. Sztychmiler, Komentarz do Kodeksu Prawa Kanonicznego, t. 5, s. 422-423. 
jąc się powtórnie dopiero w schemacie De procedura administrativa z 1972 r. Papieskiej Komisji do Spraw Reformy CIC ${ }^{11}$.

\subsection{Prośba do autora dekretu w ujęciu historycznym}

Mimo, iż przed powstaniem prawa dekretałów w Kościele trudno było wyodrębnić władzę administracyjną i sądową, to jednak już wówczas istniały środki ochrony prawnej, z których korzystali wierni czujący się pokrzywdzeni określoną decyzją władzy kościelnej. Brak ścisłości pojęć prawnych używanych w tamtym okresie nie pozwala na dokładne ustalenie, czy środki te stosowane były wobec aktów administracyjnych we współczesnym rozumieniu. Można jednak już wtedy wskazać na trzy rodzaje środków odwoławczych stosowanych przeciwko decyzjom administracyjnym: suplikację, apelację seu rekurs hierarchiczny i bezpośredni rekurs do papieża. Prośba skierowana do autora aktu określana była mianem suplikacji (supplicatio), która z czasem została nazwana rekursem łaski. Stosowana była właściwie w całym okresie poprzedzającym prawo dekretałów, zwłaszcza zaś w dekrecie Gracjana można odnaleźć odnoszące się do niej konkretne wzmianki ${ }^{12}$.

W drugim okresie rozwoju kościelnej sprawiedliwości administracyjnej, trwającym od prawa dekretałów do reformy Kurii Rzymskiej papieża Piusa X w 1908 r., można zaobserwować następujący sukcesywny rozdział kompetencji organów władzy kościelnej sprawujących kontrolę nad funkcjonowaniem administracji. Także w tym okresie suplikacja, zwana rekursem łaski bądź remonstratio, posiadała charakter prośby skierowanej do autora aktu (nakazu), celem uchylenia obowiązku jego wykonania. Papież Aleksander III w prawie dekretałów nakazał biskupowi zadośćuczynić przedstawianym mu suplikacjom, mając na uwadze wymogi sprawiedliwości i obowiązki związane $\mathrm{z}$ jego urzędem ${ }^{13}$.

\footnotetext{
${ }^{11}$ Por. J. Krukowski, Administracja w Kościele, s. 205.

${ }^{12}$ Tamże, s. 188-189; J. KRuKowski, Prawo administracyjne w Kościele, s. 492-493.

${ }^{13}$ J. Krukowski, Administracja w Kościele, s. 191; J. KruKowski, Prawo administracyjne w Kościele, s. 495-496.
} 
W trzecim okresie, a zatem od reformy Piusa X do reformy Pawła VI w 1967 r., prośba do autora aktu zostaje niejako „przemilczana” przez prawodawcę, który skoncentrował swoją uwagę na rekursie hierarchicznym do kongregacji Kurii Rzymskiej, jako środku odwoławczym rozstrzygającym spory administracyjne. Wyłączenie działalności administracyjnej spod kontroli sądowej dokonane przez papieża Piusa X w roku 1908, znalazło potwierdzenie w Kodeksie Prawa Kanonicznego z 1917 roku. Taki system rozwiązywania sporów administracyjnych został jednak skrytykowany przez kanonistów, zwłaszcza w okresie soborowej odnowy Kościoła ${ }^{14}$. Wówczas właśnie, Papieska Komisja do Spraw Reformy CIC przedstawiła nowy model systemu tejże sprawiedliwości we wspomnianym już schemacie De procedura administrativa, rozesłanym do zaopiniowania w 1972 r. konferencjom biskupów oraz dykasteriom Kurii Rzymskiej. Reforma kościelnego prawa administracyjnego przedstawiona w tymże schemacie, zakładała między innymi wprowadzenie środków odwoławczych, których celem byłoby zapobieżenie powstaniu sporu administracyjnego. Wśród nich na pierwszym miejscu znalazła się prośba do autora aktu o odwołanie go lub poprawienie ${ }^{15}$.

\subsection{Prośba do autora dekretu w aktualnych przepisach kodeksowych}

Zgodnie z nakazem kodeksowym zawartym w kan. 1734 §1, przed zgłoszeniem rekursu hierarchicznego, do autora aktu należy wnieść pisemna prośbę o odwołanie lub poprawienie dekretu. Prośba wyrażona tylko ustnie nie rodzi skutków prawnych ${ }^{16}$; winna mieć charakter pisma formalnego, to jest petycji lub listu, jednoznacznie wskazywać, jakiego aktu administracyjnego dotyczy i wnosić o jego odwołanie lub poprawienie $^{17}$. Motywem takiej prośby winno być przekonanie zain-

${ }^{14}$ J. KruKowski, Administracja w Kościele, s. 200; por. J. KRUKOwsKI, Prawo administracyjne w Kościele, s. 502-505.

${ }^{15}$ J. Krukowski, Administracja w Kościele, s. 204; J. Krukowski, Prawo administracyjne w Kościele, s. 505 i 509.

${ }^{16}$ J. Krukowski, Prawo administracyjne w Kościele, s. 513.

${ }^{17}$ E. LabandeIra, Trattato di diritto amministrativo canonico, s. 459-460. 
teresowanego o krzywdzie wyrządzonej dekretem (kan. 1733 §1), zaś przyczyną tejże szkody może być wadliwość aktu administracyjnego pod względem formalnym (nielegalność) bądź merytorycznym ${ }^{18}$. Podmiot, przeświadczony o krzywdzie wyrządzonej dekretem administracyjnym, którego jest adresatem, winien wykazać, iż przeświadczenie to oparte jest na przesłankach obiektywnych, a zatem wynikających ze słuszności, sprawiedliwości i prawa a nie z racji tylko subiektywnych. Organ władzy wykonawczej zobowiązany jest dokładnie zbadać motyw odwołania od aktu administracyjnego, którego celem jest zachowanie praworządności i sprawiedliwości w życiu społecznym, co - z drugiej strony - rodzi u wiernych, tak świeckich jak i duchownych, obowiązek zachowania posłuszeństwa względem pasterzy i przełożonych, którzy mocą prawa wydają określone decyzje ${ }^{19}$. Pismo może być przedstawione bezpośrednio w kancelarii lub sekretariacie, które wydadzą stosowne zaświadczenie o jego przyjęciu lub o rejestracji prośby, bądź też może być wysłane jako list polecony za potwierdzeniem odbioru $^{20}$.

Tego rodzaju prośbę, zwaną niekiedy suplikacją czy petycją, adresat aktu może wnieść w terminie dziesięciu dni od otrzymania legalnego zawiadomienia o wydaniu aktu (kan. 1734 §2) ${ }^{21}$. Samo zaś uzasadnienie prośby można wnieść w terminie późniejszym ${ }^{22}$.

Autor aktu zobowiązany jest rozpatrzeć wniesioną do niego prośbę w terminie 30 dni. Odwołanie dekretu skutkuje naturalnie ustaniem przedmiotu wniesienia nowego rekursu. Jeśli zaś w tym czasie zainteresowany rozstrzygnięciem sprawy otrzyma nowy dekret, który zawiera niezadowalającą go odpowiedź, bądź też jego prośba zostanie odrzucona przez przełożonego, wówczas, od dnia otrzymania tego nowego dekretu, zaczyna płynać czas do wniesienia rekursu hierarchicznego do przełożonego hierarchicznie wyższego od autora aktu. Jeśli zaś przez

${ }^{18}$ J. Krukowski, Prawo administracyjne w Kościele, s. 513.

${ }^{19}$ T. Pawluk, Prawo Kanoniczne wedtug Kodeksu Jana Pawła II, t. 4, Doczesne dobra Kościoła, Sankcje w Kościele, Procesy, Olsztyn 1990, s. 390.

${ }^{20}$ E. LabandeIra, Trattato di diritto amministrativo canonico, s. 460.

${ }^{21}$ P. Majer (red.), Kodeks Prawa Kanonicznego. Komentarz, s. 1302.

${ }^{22}$ J. Krukowski, Prawo administracyjne $w$ Kościele, s. 513. 
owe 30 dni autor aktu, do którego została skierowana prośba o jego poprawienie lub odwołanie, nie podjął żadnej decyzji, co jest równoznaczne $z$ odpowiedzią negatywna, terminy na wniesienie rekursu biegną od trzydziestego dnia milczenia ${ }^{23}$. Takie jednak domniemanie odpowiedzi negatywnej nie zwalnia kompetentnej władzy od obowiązku wydania nowego aktu ani też od obowiązu naprawienia ewentualnej szkody, wynikłej z milczenia ${ }^{24}$. Prawodawca wyraźnie zobowiązuje bowiem każdego „ktokolwiek aktem prawnym nielegalnie albo jakimkolwiek innym aktem dokonanym z winy umyślnej lub nieumyślnej wyrządził komuś krzywdę" do naprawienia wyrządzonej szkody ${ }^{25}$.

Obowiązek wniesienia prośby do autora aktu przed wniesieniem rekursu hierarchicznego nie jest jednak bezwzględny. Prawodawca wskazuje na sytuacje wyjątkowe, które zwalniają petenta $\mathrm{z}$ tegoż obowiązku. A zatem, prośba do przełożonego - autora aktu - o poprawienie lub odwołanie aktu administracyjnego nie musi być wnoszona wówczas, gdy rekurs został wniesiony do biskupa przeciwko dekretom, których autorami są podlegające mu organy władzy; w ten sposób podkreślona została władza biskupa diecezjalnego będącego zwierzchnikiem Kościoła partykularnego, który jest jedynym uprawnionym do przyjmowania odwołań od aktów podlegających mu hierarchicznie władz. Drugi przypadek niedomagający się prośby do autora aktu ma miejsce wówczas, gdy zaskarżany dekret jest dekretem rozstrzygającym rekurs hierarchiczny, chyba że decyzja ta została wydana przez biskupa ${ }^{26}$. Ostatnią zaś sytuacją podaną przez prawodawcę jest ta, gdy rekurs został zgłoszony przeciwko decyzji odmownej lub milczeniu administracyjnemu organu, który był zobowiązany wydać akt z mocy samego prawa, czy na prośbę jednostki administrowanej lub wówczas, gdy rekurs został wniesiony wobec dekretu wydanego na

${ }^{23}$ P. MAJer (red.), Kodeks Prawa Kanonicznego. Komentarz, s. 1303; J. KRUKOWSKI, Prawo administracyjne $w$ Kościele, s. 515.

${ }^{24} \mathrm{KPK} / 83$, kan. $57 \S 3$.

${ }^{25} \mathrm{KPK} / 83$, kan. 128.

${ }^{26} \mathrm{KPK} / 83$, Kan. 1734 §3, n. 2. 
prośbę o uchylenie aktu administracyjnego, o którego poprawienie została skierowana prośba do jego autora (por. kan. 57 i 1735) ${ }^{27}$.

Prośba zaś wniesiona do dykasterii Kurii Rzymskiej o zmianę bądź poprawienie dekretu zawierającego rozstrzygnięcie sporu administracyjnego, zwana jest beneficium novae audientiae i rozpatrywana jest zgodnie z Regulaminem Generalnym Kurii Rzymskiej, art. $134-138^{28}$.

3.3. Skutki wniesienia prośby o odwołanie lub poprawienie dekretu

Prośba do autora aktu administracyjnego o poprawienie go lub odwołanie nie jest zwykłą prośbą o łaskę, gdyż rodzi po stronie autora aktu obowiązek ponownego ustosunkowania się do całokształtu sprawy będącej przedmiotem aktu. Obowiązek ten wynika ze skutku przekazującego (effectus devolutivus) prośby o odwołanie lub poprawienie dekretu, który zawsze wiąże się z faktem wniesienia prośby do autora dekretu.

W tym co odnosi się do skutku zawieszającego (effectus suspensi$v u s)$, który polega na zawieszeniu wykonania zaskarżonego dekretu, w czasie od wniesienia prośby do autora aż do wydania przez niego decyzji rozstrzygającej - zdaniem prawodawcy - sam fakt wniesienia tego rodzaju prośby należy pojmować jednocześnie jako prośbę o zawieszenie wykonania aktu będącego przedmiotem prośby (kan. 1734 $\S 1)^{29}$. Samo wniesienie prośby do autora dekretu o jego zmianę bądź odwołanie powoduje skutek zawieszający wykonanie aktu w tych wypadkach, w których wniesienie rekursu hierarchicznego rodzi skutek zawieszający na mocy samego prawa (kan. $1736 \S 1)^{30}$. Są to prośby dotyczące następujących dekretów: wydalenia członka instytutu życia konsekrowanego (kan. 700); wymierzenia kary (kan. 1353 odnośnie

${ }^{27}$ J. KRUKOwSKI, Prawo administracyjne w Kościele, s. 514; E. LABANDEIRA, Trattato di diritto amministrativo canonico, s. 461.

${ }^{28}$ J. Krukowski, Prawo administracyjne $w$ Kościele, s. 514.

${ }^{29}$ J. KruKowski, Administracja w Kościele, s. 206.

${ }^{30}$ J. Krukowski, Prawo administracyjne w Kościele, s. 519; E. LabandeIra, Trattato di diritto amministrativo canonico, Milano 1994, s. 460. 
do kan. 1319, 1342 §1, 1720); pozbawienia urzędu kościelnego, o ile prawo w określonych przypadkach nie stanowi inaczej (kan. 143 §2); a także dekretu usunięcia proboszcza z parafii, wydanego przez biskupa, ponieważ w okresie trwania rekursu biskup nie może mianować nowego proboszcza a jedynie tymczasowo - administratora parafii (kan. 1747 §3 i 1752).

Jeśli zaś prawo nie dołącza skutku zawieszającego do prośby o zmianę lub poprawienie dekretu, zawieszenie jego wykonania może nastąpić na mocy dekretu wydanego przez autora zaskarżonego aktu, na skutek prośby wniesionej przez adresata aktu w terminie dziesięciu dni od zawiadomienia o dekrecie. W razie odmowy petent może wnieść prośbę o zawieszenie aktu do przełożonego hierarchicznego wobec autora aktu. Warunkiem decyzji o zawieszeniu wykonania dekretu jest, z jednej strony przedstawienie poważnych przyczyn przez petenta, a po stronie organu wydającego nakaz zawieszający - troska o to, aby

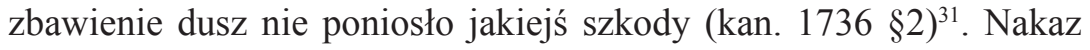
o zawieszeniu wykonania dekretu, co do którego wpłynęła prośba do jego autora o odwołanie lub zmianę, może mieć miejsce - decyzją przełożonego - także wtedy, gdy mimo braku prośby o zawieszenie aktu, wystapiły poważne przyczyny a dobro duchowe nie odniesie szkody (kan. 1736 §; 1737 §). Poważna przyczyna, która zawsze warunkuje wydanie dekretu zawieszającego wykonanie zaskarżonego aktu, ma zostać rozpoznana przez przełożonego hierarchicznego, którego roztropnej ocenie powierza się weryfikację danej sytuacji. Pragnienie zapobieżenia powstaniu szkody publicznej czy nawet prywatnej, której naprawienie byłoby zadaniem niełatwym po uchyleniu mocy wiążącej danego aktu, stanowić może główny wyznacznik działania kompetentnego przełożonego w tejże materii ${ }^{32}$.

Wprowadzone tymczasowo zawieszenie wykonania aktu, co do którego została wniesiona prośba o jego odwołanie lub poprawienie, ustaje, jeżeli po upływie ustalonych terminów nie zostanie wniesiony żaden rekurs przeciwko dekretowi (kan. 1736, § 4); w przypadku jego

\footnotetext{
${ }^{31}$ Por. J. KRUKowski, Administracja w Kościele, s. 206.

32 J. Krukowski, Prawo administracyjne w Kościele, s. 520-521.
} 
wniesienia, ten kto ma rozpatrzyć rekurs, winien rozstrzygnąć, czy zawieszenie należy potwierdzić czy odwołać (kan. 1736, §3).

\section{Zwrócenie się obu stron do mediatorów}

Praktyka mediacji poprzez sądy polubowne, jako środka pojednawczego w sporach cywilnych, znana była już w prawie przedkodeksowym jak i w Kodeksie Prawa Kanonicznego z 1917 r. Dopiero jednak w schemacie procedury administracyjnej z 1972 r. wysunięto projekt zastosowania jej także w sporach administracyjnych. Zalecono, aby wówczas gdy prośba do autora aktu o poprawienie lub odwołanie go nie przyniosła oczekiwanych efektów, przeprowadzić postępowanie pojednawcze pomiędzy adresatem i autorem aktu. Według schematu inicjatywa takiego działania mogła pochodzić tak ze strony bezpośrednio zainteresowanych (autora dekretu i jego adresata), jak i ze strony przełożonego hierarchicznego lub trybunału administracyjnego, do którego został wniesiony rekurs administracyjny. W tym ostatnim przypadku organ, do którego został wniesiony rekurs, jeszcze przed jego przyjęciem, był zobowiązany do wezwania stron do polubownego poszukiwania słusznego uniknięcia lub rozwiązania sporu administracyjnego. W schemacie ogólnie stwierdzono, iż należy poszukiwać tego rodzaju rozwiązania za pośrednictwem mediatorów lub komisji, które skłoniłyby autora do dobrowolnego poprawienia aktu lub słusznej kompensaty, lub jakiejś innej słusznej drogi uniknięcia sporu ${ }^{33}$.

W aktualnie obowiązującym Kodeksie dokonano pewnej modyfikacji powyższej propozycji. Wyraźnie rozgraniczono dwa odmienne środki zapobieżenia powstaniu sporu administracyjnego, a mianowicie: zwrócenie się obu stron do mediatorów oraz zwrócenie się tychże do - specjalnie w tym celu powołanego przez konferencję biskupów czy danego biskupa - urzędu bądź komisji.

W sytuacji zwrócenia się do mediatorów strony, między którymi istnieje różnica zapatrywań na treść wzajemnych roszczeń, w sposób dobrowolny wybierają osoby, które cieszą się u nich autorytetem i po-

${ }^{33}$ Por. J. Krukowski, Administracja w Kościele, s. 207. 
ważaniem, prosząc o rozstrzygnięcie wątpliwości prawnej i zobowiązując się podporządkować wydanemu postanowieniu, zapobiegając w ten sposób powstaniu sporu lub doprowadzając do jego zakończenia, jeśli już zaistniał (kan. 1733 §1) 34 $^{34}$ Okoliczności każdego przypadku będą determinowały cechy charakterystyczne mediatorów, do których wniesiona zostanie prośba o pomoc w rozwiązaniu konfliktu i niedopuszczeniu do powstania sporu w sensie formalnym, poprzez osiagnięcie porozumienia. Osoby te winny cieszyć się zaufaniem zainteresowanych stron, być zdolne do godzenia osób znajdujących się w konflikcie, a także cechować się szczególną roztropnością ${ }^{35}$. Do użycia tego rodzaju środka pojednawczego niezbędna jest zgoda obu stron, które zazwyczaj poprzez zawarcie stosownej umowy, wyrażają aprobatę na zastosowanie tego rodzaju środka pojednawczego. Ważne jest, iż z pomocy mediatorów można korzystać na każdym etapie sporu także po wniesieniu rekursu hierarchicznego lub skargi do trybunału administracyjnego, a nie tylko przed jego powstaniem. Nie zawsze jednak jest możliwe skorzystanie z pomocy mediatorów, ze względu na wspomnianą już klauzulę ograniczającą przedmiot rozwiązania sporu w tenże sposób (kan. 1715) ${ }^{36}$.

\section{Odwołanie się do urzędu lub komisji pojednawczej}

Ostatnim ze wskazanych przez prawodawcę kodeksowego środków pojednawczych jest możliwość odwołania się do specjalnego urzędu czy komisji, których zadaniem jest doprowadzenie przełożonego i adresata wydanego przezeń aktu administracyjnego, do pojednania na drodze kompromisu. Norma zawarta w kanonie 1733, §§2 i 3 nie ma jednak charakteru obligatoryjnego, lecz fakultatywny, tzn. wyposaża konferencje biskupów, ewentualnie poszczególnych biskupów diecezjalnych w określone kompetencje. Tak więc konferencja biskupów może postanowić, aby w każdej diecezji został ustanowiony na sposób

${ }^{34}$ J. Krukowski, Prawo administracyjne w Kościele, s. 516.

${ }^{35}$ J. Miras, J. Canosa, E. Baura, Compendio di diritto amministrativo canonico, S. 332-333.

${ }^{36}$ J. KruKowski, Prawo administracyjne w Kościele, s. 516-517. 
stały pewien urząd lub komisja, których zadaniem byłoby poszukiwanie i sugerowanie słusznych rozwiązań skierowanych na uniknięcie powstania sporu administracyjnego. Konferencja biskupów, powołując tego rodzaju organy, powinna również wydać odpowiednie normy, według których mają one postępować. Gdyby zaś konferencja biskupów nie skorzystała z przyznanych jej kompetencji, wówczas poszczególni biskupi diecezjalni, jak i zwierzchnicy kościołów partykularnych, zrównani w prawie z biskupem diecezjalnym, mogą powołać tego rodzaju instytucje w swoich diecezjach ${ }^{37}$. Oni też powinni wydać odpowiednie przepisy regulujące działalność tychże organów. E. Labandeira podaje, iż tego rodzaju funkcja mogłaby zostać powierzona kolegium konsultorów ${ }^{38}$.

Tego rodzaju urząd czy komisja pojednawcza winna podjąć stosowne działania szczególnie wówczas, gdy skierowana została prośba do autora aktu o jego poprawienie lub odwołanie, zaś terminy na wniesienie rekursu hierarchicznego jeszcze nie upłynęły. Gdy zaś rekurs został już wniesiony, wówczas sam przełożony hierarchiczny winien zachęcić strony ewentualnego sporu, aby zwróciły się o pomoc do organu pojednawczego, zapobiegając jego powstaniu ${ }^{39}$.

Zadaniem tegoż organu pojednawczego jest ,poszukiwanie i sugerowanie słusznych rozwiązań" nastawionych na niedopuszczenie do powstania sporu administracyjnego, zwłaszcza wtedy, gdy prośba do autora aktu o jego odwołanie lub poprawienie nie została spełniona (kan. $1734)^{40}$. Organ ten nie jest kompetentny, w przeciwieństwie do sądu arbitrażowego, do wydania decyzji bezwzględnie wiążącej czy to wiernego, który czuje się zbyt obciążony aktem administracyjnym, czy też przełożonego będącego autorem tegoż aktu. Może natomiast wezwać

${ }^{37}$ J. Krukowski, Administracja $w$ Kościele, s. 208-209; J. KRUKowski, Prawo administracyjne $w$ Kościele, s. 518; T. Pawluk mówi o diecezjalnej komisji do administracyjnych spraw odwoławczych lub specjalnym urzędzie diecezjalnym. T. PAwLUK, Prawo Kanoniczne wedtug Kodeksu Jana Pawła II, t. 4, s. 391.

${ }^{38}$ E. LabandeIrA, Trattato di diritto amministrativo canonico, s. 458.

${ }^{39}$ J. Krukowski, Administracja w Kościele, s. 209.

${ }^{40}$ J. Krukowski, Prawo administracyjne w Kościele, s. 518. 
adresata aktu do przyjęcia postanowień dekretu bądź też jego autora - do poprawienia lub odwołania wydanego aktu ${ }^{41}$.

W rezultacie dyspozycji kanonu 1733 konferencje biskupów USA, Wielkiej Brytanii i Irlandii Północnej, Włoch i Nowej Zelandii, ustanowiły w swoich Kościołach partykularnych tego typu organy pojednaw$\mathrm{cze}^{42}$. Niewątpliwie, pełnią one niezmiernie istotną rolę, jeśli chodzi o realizację uprawnienia wszystkich wiernych Kościoła do legalnego dochodzenia i obrony przysługujących im praw (kan. $221 \S 1$ ). Zawsze jednak, o czym była mowa powyżej, na drodze wykonywania tychże praw, tak przez poszczególnych wiernych jak i przez tych zrzeszonych w stowarzyszeniach, należy mieć na uwadze dobro wspólne Kościoła, uprawnienia innych, jak również własne obowiązki względem drugich, a w związku z tym także umiar w korzystaniu z przysługujących praw, co winno być kontrolowane przez kompetentną władzę kościelną (kan. 223 § i 2). Dlatego też należy podkreślać potrzebę powoływania tychże organów pojednawczych w diecezjach, nie tylko ze względu na konkretne sporne kwestie administracyjne, w których rozwiązaniu czy nawet zapobieżeniu powstaniu formalnego sporu będą pełniły pierwszorzędną rolę, ale także na ich doniosłe znaczenie w kształtowaniu ewangelicznej świadomości o potrzebie dążenia do budowania communio kościelnej w duchu braterskiej miłości ${ }^{43}$.

${ }^{41}$ J. Krukowski, Prawo administracyjne $w$ Kościele, s. 519; por. F. D’Ostilio, Il diritto amministrativo della Chiesa, s. 468.

${ }^{42}$ G. Erlebach, A. Dzięga, J. Krukowski (red.), R. Sztychmiler, Komentarz do Kodeksu Prawa Kanonicznego, t. 5, s. 425. Konferencja Episkopatu Włoch w grudniu 1983 r. pozostawiła zadanie poszukiwania słusznych rozwiązań sporów wynikłych na skutek odwołań (rekursów) od aktów administracyjnych poszczególnym biskupom, nie podejmując - przynajmniej na razie - decyzji o powołaniu specjalnego urzędu czy stałej rady, zajmującej się tego rodzaju działalnością (F. D’OstiLıo, Il diritto amministrativo della Chiesa, s. 467-468). Także Konferencja Episkopatu Polski nie podjęła w tym zakresie żadnych działań, ale w kilku polskich diecezjach, z inicjatywy biskupów diecezjalnych, tego rodzaju urzędy zostały ustanowione. Dla przykładu w Archidiecezji Lubelskiej, dekretem z dnia 18 listopada 2004 r., N.1047/Gł/2004 powołał, na mocy kan. 1733 §2 Archidiecezjalny Zespół Interwencyjny, w celu nadzwyczajnej koordynacji działań w następstwach sytuacji kryzysowych.

${ }^{43}$ Por. 1 Kor $13,4-6$. 
Nie ma wątpliwości co do tego, że także rekurs hierarchiczny rozstrzyga spór, jednak czyni to za pomocą aktu władzy narzucającego stronom rozwiązanie w sposób autorytarny ${ }^{44}$. Aby tego uniknąć prawodawca kościelny stoi na stanowisku, iż nawet wniesienie rekursu w terminach określonych $\mathrm{w}$ prawie, nie wyklucza w żaden sposób możliwości osiagnięcia porozumienia na drodze polubownej. Nawet jeśli, zgodnie z kan. $1733 \S 3$, najwłaściwszym czasem na podjęcie próby alternatywnego rozwiązania sporu jest okres po przedstawieniu wcześniejszej prośby przewidzianej w kan. 1734 i przed upływem terminów na wniesienie rekursu, to jednak nic nie stoi na przeszkodzie, aby także wtedy, gdy ten już zostanie wniesiony, kontynuowane było poszukiwanie rozwiązania sporu za wspólnym porozumieniem zainteresowanych stron ${ }^{45}$.

\section{Uwagi końcowe}

Funkcjonowanie środków odwoławczych od decyzji organów pełniących funkcję władzy wykonawczej w Kościele, a ściśle rzecz biorąc - omówionych powyżej środków polubownych, stanowi nie tylko sposób uniknięcia sporu na płaszczyźnie zależności hierarchicznej, ale także jest w ogóle, istotnym czynnikiem kształtującym funkcjonowanie kościelnej sprawiedliwości administracyjnej. Ta bowiem powinna być zawsze ukierunkowana na poszanowanie godności osoby ludzkiej oraz brać pod uwagę ochronę uprawnień człowieka, zwłaszcza zaś tych, które posiada on z racji przynależności do Kościoła. Ponadto, mając na względzie szerszą autonomię organów administracyjnych w Kościołach partykularnych, należy podejmować z coraz większą pilnością i zaangażowaniem zadanie czuwania nad działalnością poszczególnych podmiotów sprawujących funkcję władzy wykonawczej. Z pewnościa, promowanie stosownych polubownych dróg porozumienia i pojednania na drodze pojawiających się sporów, które w każdej wspólnocie ludzkiej, także w Bosko-ludzkiej wspólno-

${ }^{44}$ J. Miras, J. Canosa, E. Baura, Compendio di diritto amministrativo canonico, s. 331 .

45 Tamże, s. 334. 
cie Kościoła, są nieuniknione, jest wyzwaniem szczególnie istotnym, zwłaszcza w czasach prymu nieskrępowanej wolności i bezwzględnej walki o ochronę praw, z pominięciem każdemu przynależnych, prawnie określonych obowiązków. Właściwe organy władzy w Kościele, tak na poziomie konferencji biskupów jak i poszczególnych diecezji, winny zatem, w trosce o dobro wspólne powierzonej ich pieczy wspólnoty wiernych, usilnie dazżyć do zabezpieczenia sprawiedliwości administracyjnej już w momencie stanowienia danych aktów wykonawczych, ale także - wzmacniając gwarancję jej poprawnego funkcjonowania - poprzez powoływanie stosownych organów, służących pomocą w sytuacjach konfliktowych, czy też prowadzących do powstania ewentualnego sporu.

\section{Conciliation in settling administrative recourses according to the regulations of the Latin Church}

Protection of the rights of physical and legal entities belongs to the principal functions of the authorities and the legal system of each social organism. A new look at the Church, especially after the Vatican Council II, encouraged far reaching protection of subjective rights in the Church.

The available measures that are now provided for by the code legislator and whose direct aim is to prevent the occurrence of an administrative recourse in the formal sense, include seeking from the author of the act the revocation or amendment, addressing mediators, referring the matter to be examined by an office or council established by the Conference of bishops or a particular bishop (can. 17331734). The material scope of the acts, against which conciliatory measures can be instituted in the Church, was determined in can. 1732. These are all singular administrative acts, especially decrees and concrete orders issued in the external forum outside a trial except those which have been issued by the Roman Pontiff or an ecumenical council.

A request to the author of an administrative act for revocation or amendment, aimed at avoiding obedience to it in life, is not an ordinary request for a favour since it places an obligation upon the author to take an attitude again to the whole matter being the object of the act (can. $1734 \S 1$ ). Mediation means the parties in danger of a conflict turning to serious-minded persons enjoying authority with a request to settle the recourse, at the same time making an obligation to subordinate to the solution suggested by them (can. $1733 \S 1$ ). Moreover, the legislator of the code provides the Conferences 
of bishops with the right to establish in a stable manner an office or council, whose task would be to seek and suggest equitable solutions and to lay down the norms regulating the work of these bodies. Should the Conference not use this right, such a council can be established by the bishop for his Church (can. $1733 \S 2-3$ ). 